\title{
John Dewey on the Reflective Moral Life: Renewing His Lessons for Moral Education Today
}

\author{
Jessica Ching-Sze Wang \\ National Chiayi University, Taiwan
}

\begin{abstract}
Moral education as practiced in schools today roughly falls into two kinds, either taught as an independent subject or practiced as a form of school-wide social learning. Dewey’s criticism of rigid moral training in traditional schools gives credence to the latter trend. For instance, in 2000 Taiwan's Ministry of Education decided to eliminate moral education as a required subject from the national school curriculum and suggested that all schools and teachers should infuse morality into the school culture as a whole. More than a decade has passed, and many people question whether schools have been infused with morality. Some even suggest that not teaching morality in schools has led to an eroding of moral standards in society at large. In light of this controversy, in this paper, I take a close look at Dewey's conception of the nature of morality, and in particular, his distinction between reflective and customary morality. Drawing on Dewey’s own moral struggles in life to illustrate his major contentions, I explore what Dewey means by moral reflection, dramatic rehearsal, and growth. Finally, I argue for the importance of committed moral values as the foundation for realizing Dewey's ideal of reflective intelligence. Overall, I aim to unpack the underlying assumptions in Dewey’s ideas in order to renew his lessons for moral education today.
\end{abstract}

Keywords: Dewey, moral education, moral reflection, the dramatic rehearsal, reflective intelligence, growth, moral values

\section{Moral Reflection, Inquiry, and Growth}

Unlike moral theorists who prescribe certain virtues or duties to account for the nature of morality, Dewey refuses to "postulate one single principle as an explanation of moral life” (LW 5, 280). ${ }^{1}$ As Festenstein (1997) notes, Dewey "does not attempt to provide an external vindication of an 'ultimate law'... but an internal elucidation of what it is to be a moral agent” (46). Asserting that a moral agent is someone who reflects upon moral conflicts when they arise, Dewey stresses an important distinction between "customary" morality and "reflective" morality. The former "places the standard and rules of conduct in ancestral habit," whereas the latter "appeals to conscience, reason, or to some principle which includes thought" (LW 7, 162).

According to Dewey, if one has "a positive belief as to what is right and what is wrong," he or she cannot be said to be engaging in reflective morality ( $\operatorname{~WW~7,~164).~Moral~reflection~emerges~only~when~one~is~}$ "confronted with situations in which different desires promise opposed goods and in which incompatible courses of action seem to be morally justified." Only such a moral conflict calls forth "personal inquiry into the bases of morals" (LW 7, 164). One has to experience a conflict between two morally justifiable convictions or

Jessica Ching-Sze Wang, Ph.D., associate professor, Department of Education, National Chiayi University, Taiwan; main research field: Educational Philosophy of John Dewey and Philosophy for Children. 
actions in order to deeply reflect upon them.

Dewey delineates an alternative conception of moral conflict to replace traditional paradigms of morality that treat conflict as arising simply from "an anguish of the will” divided between good and evil, justice and injustice, duty and caprice, virtue and vice (LW 5, 280), as would likely occur in the case of a bank employee embezzling funds. Although this kind of moral struggle is "the most emphasized in moral writings and lectures" (LW 7, 164), Dewey does not think that it engages one in genuine reflection. Genuine reflection requires a conflict, not between good and bad, but as "an inherent part of the good, the obligatory, the virtuous" (LW 5, 280). Dewey contends that only this particular form of conflict is truly worthy of the descriptive term "moral." He provides a telling example:

Take... the case of a citizen of a nation which has just declared war on another country. He is deeply attached to his own State. He has formed habits of loyalty and of abiding by its laws, and now one of its decrees is that he shall support war. He feels in addition gratitude and affection for the country which has sheltered and nurtured him. But he believes that this war is unjust, or perhaps he has a conviction that all war is a form of murder and hence wrong... Now he has to make $a$ choice between competing moral loyalties and convictions... He is forced to reflect in order to come to a conclusion. (LW $7,164)$

In this case, the person engages himself in reflective morality by having to make a conscious choice between two moral values—-patriotic commitment and pacifist conviction.

This example deserves special attention because it is drawn from Dewey's own moral struggle during the First World War. At that time, America was torn between whether or not to enter into the war in Europe. Much to the dismay of his friends, the humanist and democratic Dewey supported U.S. intervention in the war. Dewey's pacifist friends, Randolph Bourne and Jane Addams, broke party with him on the grounds that Dewey had betrayed his own democratic principles. Refusing to commit to peace as a universally unquestionable moral end, Dewey instead engaged in deliberation and judgment by surveying practical facts and attending to contextual needs. Dewey thought that peace by itself was "only a negative idea;" and he judged that "there were ideals more important than keeping one's body whole and one's property intact” (MW 8, 203). Thus, Dewey decided to endorse America's entry into the war as a potentially intelligent use of force that was needed at a particular time, in a particular context, and for a particular purpose.

This important example illustrates what I take to be Dewey's "intellectualized" account of morality: Namely, morality is a matter of judging the good in each conflicting situation. Here the point is not about choosing the "right" course over the "wrong" course. The "moral" element lies in the quality of reflection involved in the conflict-ridden situation itself and the reflective habits of mind that have consequently been reinforced or retarded. Dewey is concerned with whether and how this experience as a whole affects one's habits, strengthens one's character, and contributes to one's growth. Dewey sees the moral life not as an accumulation of discrete moral acts performed out of immediate deference to prescribed moral rules or virtues, but as an expression and expansion of one's habits and character. "The thing actually at stake in any serious deliberation," Dewey contends, "is not a difference of quantity, but what kind of person one is to become, what sort of self is in the making, what kind of world is (in the) making” (MW 14, 150). In each case of moral reflection, one is choosing to become a certain kind of person, effecting and creating a certain kind of world—and this is what ultimately matters.

Therefore, in moral education, Dewey advocates a shift of emphasis from customary morality to reflective morality, from "conformity to prevailing modes of action over to personal disposition and attitudes" (LW 7, 
166). Dewey characterizes the development of a well-formed moral character as a continuous sharpening of certain reflective dispositions and habits—such as sensitivity, open-mindedness, conscientiousness, courage, imagination, and sympathy (Pappas 2008). A robust moral character and a persistent moral self are the desired goals of Deweyan moral education.

\section{The Dramatic Rehearsal in Moral Reflection}

Since reflection is a key element in Dewey's moral philosophy and his proposal for moral education, the next question is how to reflect. His notion of the "dramatic rehearsal" can help us understand how the moral agent is to deliberate about a moral choice. First, Dewey makes it clear that the moral agent should avoid taking overt action rashly when there is a clash between a "prior habit" and a "newly released impulse" (MW 14, 132). One should take the time and make the effort to play out a mental drama in one's mind, to try out an imaginary experiment, in order to "uncover the conflict in its full scope and bearing." As Dewey explicates, "what we want to find out is what difference each impulse and habit imports, to reveal qualitative incompatibilities by detecting the different courses to which they commit us, the different dispositions they form and foster, the different situations into which they plunge us" (MW 14, 150).

John McVea (2007) points out some underlying assumptions in Dewey's notion of the dramatic rehearsal. First, Dewey assumes that emotions and impulses serve as catalysts and facilitators of the reflective process. Moral reflection requires "engagement of one's emotional, imaginative, and moral capacities to dramatically rehearse the possibilities of a situation, with a full understanding of the real people who might be involved" (McVea, 380). Dewey also assumes that the reflective moral agent does not have a complete understanding of the alternatives, risks, and consequences of the final decision. The purpose of reflection and deliberation is to discover what is preferred and truly worthy, which has little to do with quantification or maximization. As Melvin Rogers (2009) also notes, the moral agent has to draw on his own life narratives to evaluate the choices he confronts, seeks to modify, or abandons (174). In other words, the emphasis is placed on "creative deliberation about potential means that would harmonize action with the surrounding environment while allowing for the possibility that goals will emerge or evolve through the process” (McVea 2007, 381). Finally, the effect of the decision on the character of the moral agent is assumed to be more important than the actual outcome (McVea 2007). As Dewey contends,

Every... choice sustains a double relation to the self. It reveals the existing self and it forms the future self... The resulting choice also shapes the self, making it, in some degree, a new self... But every choice is at the forking of the roads, and the path chosen shuts off certain opportunities and opens others. In committing oneself to a particular course, a person gives a lasting set to his own being. Consequently, it is proper to say that in choosing this object rather than that, one is in reality choosing what kind of person or self one is going to be. (emphasis added, LW 7, 287)

In this passage, we see that the risk of moral deliberation lies less in choosing an optimal outcome than in becoming the wrong kind of person (McVea 2007, 381-2).

In his conception of reflective morality, Dewey tries to elucidate what the moral agent is going through internally — a laudable, humanistic attempt to return the subject of morality back to the human agent. We may applaud Dewey's insightful attempt to focus on the complexities of moral conflict, to harmonize contrary tendencies of the good, to offer an elucidation of the internal landscape of the moral agent, and to bridge the gap between conduct and character, but those concerned with the moral life in all its dimensions still feel compelled to confront the pressing issue of moral responsibility. In Dewey's example of the patriotic pacifist, 
he does not discuss the basis for determining the morally "higher" or "more admirable" course to choose. The point for Dewey is not so much about discovering what is the morally right decision, but about coming to know the good and realize the good for oneself - ultimately, to live up to one's own ideal of a moral self and to minimize one's sense of disintegration and loss.

Still, some perplexing questions remain unresolved: in extreme cases of moral dilemma where are decisions hard to come by, where do undesirable consequences seem unavoidable, where is harmony unachievable, where does one fall short of moral uprightness despite one's best reflective efforts, what is the moral agent to think of himself? How should he respond? Let us use Dewey's example of the patriotic pacifist to explore the issue more deeply.

\section{Revisiting the Moral Struggle in Dewey's Own Life}

Let us refer back to the struggle in Dewey's own moral life concerning his judgment of war as a potentially positive force. At the conclusion of the First World War, Dewey was disillusioned when the subsequent Versailles Conference yielded an unexpected and unjust settlement imposed by the victors who left Dewey's earlier idealistic aims utterly defeated (Wang 2007). Dewey expressed his own sense of remorse in "The Discrediting of Idealism," where he wrote, "The consistent pacifist has much to urge now in his own justification; he is entitled to his flourish of private triumphings" (MW 11, 181). Dewey analyzed the reasons for this defeat:

The ideals of the United States have been defeated... because we took into the war our sentimentalism, our attachment to moral sentiments as efficacious powers, our pious optimism as to the inevitable victory of the "right," our childish belief that physical energy can do the work that only intelligence can do, our evangelical hypocrisy that morals and "ideals" have a self-propelling and self-executing capacity. (MW 11, 182)

This experience leads Dewey to later take up a leading position in the Outlawry of War movement that urges for an international law against initiating warfare.

Although Dewey's idealism is defeated, he tries to live up to his own conception of morality, that is, his belief in the ability of the moral agent "to frame a changed ideal of self-satisfaction — that is, ability to lead a new life." This new life will be enriched with new meanings and understandings in that "the chosen end having proved itself unsatisfactory, the alternative end, previously rejected, recurs to consciousness with added claims" (emphasis added, EW 3, 343). From endorsing war to outlawing war, Dewey obviously learns some hard lessons. While the reflective moral agent is free to choose, he is also free to change-and free to grow. For Dewey, growth is the only moral end.

\section{The Moral Self in the Making: Tinkering toward Life's Consummation}

Dewey's ideal moral self is always in the making. As long as life persists, there is room for continuous growth. One may try to capture Dewey's vision of this moral ideal through the image of an accomplished sculptor working on his masterpiece, for he envisioned the moral life as a process of tinkering toward life's "consummation."

Let me use Dewey's interpretation of the artistic process in Art as Experience to illustrate this point. Dewey asserts that while the artist works, he thinks "as intently and penetratingly as the scientific inquirer" (LW 10, 52). Most importantly, the artist has a special attitude toward conflict or tension. As Dewey puts it, 
Since the artist cares in a peculiar way for the phase of experience in which union is achieved, he does not shun moments of resistance and tension. He rather cultivates them, not for their own sake but because of their potentialities, bringing to living consciousness an experience that is unified and total. (emphasis added, LW 10, 21)

For the artist, as well as for the reflective moral agent, dynamic tension is necessary and healthy-together with the need to constantly integrate these tensions into a more organic, complete, and unified whole. Dewey elaborates:

In art as an experience, actuality and possibility or ideality, the new and the old, objective material and personal response, the individual and the universal, surface and depth, sense and meaning, are integrated in an experience in which they are all transfigured from the experience that belongs to them when insolated in reflection. (LW 10, 301)

These tensions, thus integrated and transformed, bring a wealth of meanings to our hitherto mechanical and impoverished lives.

For Dewey, the moral life is characterized by its capacity to enrich meanings and to maintain balance. This reflects his unique diagnosis of the problems people face-hence the solution he offers. As Dewey comments in Experience and Nature, "the characteristic human need" is "for possession and appreciation of the meaning of things.” Dewey also states that “morals mean growth of conduct in meaning” (MW 14, 194). Without knowing the meanings embedded in our conduct, we tend to lose sight of the connection between what we do and what we undergo. Without enriched meanings, we tend to live a "narrowed, embittered, and crippled life, of congested, hurried, and extravagant life” (LW 1, 272). In Art as Experience, Dewey also remarks:

Of much of our experience as it is actually lived under present economic and legal institutional conditions, it is only too true that these separations hold. Only occasionally in the lives of many are the senses fraught with the sentiment that comes from deep realization of intrinsic meanings. We undergo sensations as mechanical stimuli or as irritated stimulations, without having a sense of the reality that is in them and behind them: in much of our experience our different senses do not unite and tell a common and enlarged story. We see without feeling; we hear, but only a second-handed report, second handed because not reinforced by vision. We touch, but the contact remains tangential because it does not fuse with qualities of sense that go below the surface. (emphasis added, LW 10, 27)

What concerns Dewey is not so much that one would lead an immoral life, but an impoverished, alienated, mechanical, meaningless, and wasteful life. As Gregory Pappas (2008) notes, "If Dewey had a general concern as an ethical thinker, it was about how a complex array of contemporary problems and conditions have contributed to the impoverished quality of moral experience" (167).

Not only is the moral life enriched by "deep realization of intrinsic meanings," it is also maintained by balance. Pappas (2008) provides a cogent analysis of balance as a moral ideal for Dewey:

The fundamental mistake of the traditional philosopher is that she misconstrues the nature of the concrete problems where $\mathrm{A}$ and $\mathrm{B}$ are in tension, thus consuming a practical tension in actual situations with a theoretical issue about what is real... The practical problem is that A and B are sometimes in an undesirable tension in the context of a problematic situation. The challenge is not to get rid of the tension but "to find the limits or balance between these two things"... From the point of view of the everyday person, the concrete problem is a matter of proportion, that is, of determining how much flexibility should be allowed in specific areas of our moral practice, or deciding what has to be changed and what does not. (emphasis added, Pappas 2008, 171)

Most paradigms of morality have led to a mechanical, rigid, and unaesthetic conception of morality. To rectify this problem, Dewey formulates a general hypothesis about a balanced life: The qualitative, proportionate balance between A and B is the relation that can make contentious experience "more educative, 
enriching and esthetic” (Pappas, 176)—and in Dewey’s rendering, quintessentially moral. As discussed earlier, genuine moral reflection and moral inquiry, with the question of the moral self at its core, contribute to a refined personality. In Arts as Experience, Dewey characterizes "this refinement of personality" as being inherently "esthetic" (Nakamura, 434). His overall portrayal of the moral life as encapsulated in the idea of tinkering toward life's consummation is more esthetic in nature than "moralistic" in the usual sense.

Let me again use the example of Dewey's own moral struggle concerning the First World War, particularly his open-minded attitude toward war as an intelligent use of force, to illustrate the ideal of balance as "a matter of proportion” (Pappas 2008). Those familiar with Dewey's writings would have no problem identifying "open-mindedness" as a key feature in Dewey's personal disposition and in his overall philosophical outlook. Open-mindedness is "an attitude of hospitality toward the new," and "a willingness to be affected by participation with the new" (Pappas 2008, 188). However, being open-minded also signifies a "rejection of absolutism” and thus naturally entails "a peculiar humility," “a recognition of one's limitations and vulnerability," and "a recognition of the precarious and open-ended character of experience” (Pappas 2008, 188).

In his judgment about the war, Dewey seemed to have leaned too much toward the image of himself as an open-minded moral self, perhaps due to his strong aversion to the contrary image of an intuitive dogmatist (as seemingly represented by his friend Randolph Bourne, the "persistent pacifist”). Although Dewey was right in believing that "anything that hardens an experience in certain lines as if they were the proper lines in which it should run becomes a burial to genuine esthetic experience" (LW 13, 362), his belief carried him too much towards the new and hence out of balance with the old - in this case, the received wisdom about the pernicious effects of war and the idea of war as the root of all evils. The following passage from Art as Experience about the imbalance "between undergoing and doing" may further drive home this point:

Experience is limited by all the causes which interfere with perception of the relations between undergoing and doing. There may be interference because of excess on the side of doing or of excess on the side of receptivity, of undergoing. Unbalance on either side blurs the perception of relations and leaves the experience partial and distorted, with scant or false meaning. Zeal for doing, lust for action, leaves many a person, especially in this hurried and impatient human environment in which we live, with experience of an almost incredible paucity, all on the surface. (LW 10, 51)

The moral quality concerned lies in the goal of balance between competing impulses, between two extremes of excess, either doing or undergoing.

The above discussions about balance and the illustration of Dewey's own moral life are intended to show that Dewey had a tendency to lean more toward the new, the changing, the contingent, the particular, and the contextual dimensions in experience-and less toward the opposite sides of the spectrum. Thus those of us who are inspired by Dewey's pragmatic moral sensibilities should be highly aware of this tendency, as we try to map out our own conception of the good and offer suggestions for moral education.

\section{Where Does the Journey of Tinkering Begin? The Foundation of Committed Moral Values}

Let us imagine the moral life as a spectrum. If fixed moral rules and absolute moral virtues mark one end of the spectrum, Dewey's notion of growth, of the moral self in the making, of tinkering towards' life consummation, marks the other end. One might say that Dewey is dealing with morality on a higher level. His vision of moral life, "his forging of the self in the stream of experience," actually prescribes a life-long journey 
of "self-cultivation" (Uffelman 2011). His demands for the moral person are no less rigorous than those prescribed in traditional paradigms. However, the question is, where this moral journey begins.

A friend of Dewey, the "persistent pacifist” Ralph Bourne, once points out an important question neglected in Dewey’s pragmatic philosophy. According to Bourne (1964), "Dewey always meant his philosophy, when taken as a philosophy of life, to start with values. But there was that unhappy ambiguity in his doctrine as to how just values are created.” Thus for Bourne, "Without the vividest kind of poetic vision,” Dewey's instrumentalism "made it easy to assume that just any growth was justified and almost any activity valuable so long as it achieved ends" (60-61). Likewise, contemporary feminist scholar Nel Noddings (1998) also questions Dewey's notion of growth by asking, "growth toward what?” Dewey's reasons for not specifying normative contents in his moral philosophy may be well grounded. As Lewis S. Feuer contends,

Dewey always questioned whether any value was “ultimate;” every statement as to what was good or valuable or desirable was from his standpoint more than an observational report of... a consummatory experience: It included as well some judgment, some reflection and conclusion, as to the relative place of the item of experience in relation to the rest of our experience. (1989, LW 15, xxi)

Rejecting ready-made rules and prescribed virtues as the answer to the moral life, Dewey prefers a heightened and vitalized sensitivity to the uniqueness of each moral situation as it presents itself in the lived world of experience.

In his rendering of sensitivity as a crucial element in moral reflection, Dewey does make an important contribution to moral theory. As he says, "there is no better evidence of a well formed moral character than knowledge of when to raise the moral issue and when not. It implies a sensitiveness to values which is the token of a balanced personality” (LW 7, 170). Dewey's underlying assumption is that the moral agent is equipped with legitimate moral values, and most importantly, with the interest to reflect upon what sort of person one becomes through every choice he or she makes. However, it is open to question whether one can reasonably assume this interest to be a point of departure. Or is it rather the end goal to achieve?

In my view, Dewey's account evades the important question about how one can be sensitive to values, and thereof to the collisions of values, if one does not commit oneself to certain values in the first place. I think that one has to care about moral values genuinely and deeply before he or she can be bothered or troubled by their collision. Those who treat morals as mere products of socialization, who see them at face value, as something external to oneself, would simply be indifferent to these values, and hence to their tensions, even if tensions do arise in everyday life. Although Dewey contends that "undoubtedly many persons are so callous or so careless that they do not raise the moral issue often enough" (emphasis added, LW 7, 170), he does not press the question further and ask what may have accounted for people's callousness or carelessness. I think the reason why people "do not raise the moral issue often enough" may lie deeper than mere callousness or carelessness. It more likely has to do with lacking a foundation of committed moral values as a guide in one's life-something Dewey fears would lead to moral indoctrination and dogmatism.

In my view, the normative foundation that Dewey refuses to specify for fear of rigidity actually plays an essential role in triggering moral reflection. Without committed moral values, people won't feel affected at a deeply emotional level, upon which his notion of the dramatic rehearsal is based. Without committed moral values, people fail to be seriously concerned about or attentive to issues of moral import, and the initial moral situation triggered by contending values that Dewey so beautifully articulates will not arise—or if it does arise, 
it will likely be a sweeping thought, lacking the required urgency it takes to move the moral agent onto the next stage of deep perplexity, and the ensuing reflection and resolution. With committed moral values, people will attend to these values as they are carried out in practice (assuming that strong commitment leads to constant and genuine practice). When putting these values into practice, one will be more likely to notice the collisions of values in real-life circumstances. After all, in the abstract world of ideas, all values look perfect in themselves; however, in the muddy world of lived experience, values tend to trump one another and thus trigger the occasion for reflective thought. Committed moral values thus serve as a foundation for moral reflection-a point Dewey does not address.

Moreover, committed moral values are important because they contribute to one's image of an ideal self, which in turn serves to invoke moral reflection. When we fall short of this moral ideal, natural moral feelings arise and make us ponder or urge us to take action. As Dewey observes in his early writings, "Moral feeling lays hold of our own true self... and says that this ought to be made real, and that our actual self must be made into conformity with it. Moral feelings involve, therefore, a gulf between the actual and the ideal or universal self” (EW 2, 290). "Our nature can be completely objectified or realized only when the chasm between what is and what ought to be, between the actual and the ideal self, is overcome” (EW 2, 290). Dewey's ideal of the self as "the growing self" is not a sufficient condition for growth itself. Moral virtues and principles may serve to provide "the flesh and bones" of a growing person, but the growing self (with the mind) needs to be embodied through flesh (virtues) and bones (principles).

The above discussion aims to drive home one important conclusion of this paper: Educators not only need to foster the habit of moral reflection as Dewey suggests, but also need to lay the essential foundation of committed moral values and principles. However, committing oneself to certain moral values is not the same as taking an epistemological stance towards whether these values bespeak "Truths" with a capital T. It is only a practical and pragmatic stance towards what moral values are worthwhile pursuing in life, be it honesty or truthfulness, justice or caring. While committed moral values mark the natural starting point of one's moral journey, they are also the natural results. As one embarks on the journey of continuous reflection upon one's experience, these values, being tested and retested, will become part and parcel of one's accumulated wisdom in life. One's commitment to these values would only grow stronger, more solid, and more grounded. Although Dewey is right that an intelligent moral agent treats every situation anew, this does not mean that every moral situation is unlike every other situation. When one accumulates wisdom in life, one tends to discover common, generalizable principles across various dimensions of human moral experience. These generalizable moral principles deserve our commitment, granted that we also endeavor to keep a balance between an open and a closed system of values. In our moral journey, we always start with some values, and end with some values.

\section{Conclusion}

I would like to conclude this paper by returning to the issue of moral education raised at the beginning, particularly about how we should renew Dewey's lessons for today. Dewey has a unique perspective about the priority of the moral problems facing modern society. He is concerned with the modern predicament of living mechanical, slavish, meaningless, and impoverished lives. Common moral problems, such as major crimes or civic transgressions, are not at the forefront of his thought. As he once states,

The evils of the present industrial and political situation, on the ethical side, are not due so much to actual perverseness on the part of individuals concerned, nor in mere ignorance of what constitutes the ordinary virtues (such as honesty, industry, 
purity, etc.) as to inability to appreciate the social environment in which we live. (emphasis added, LW 5, 73)

However, the seriousness of various moral problems in different societies or cultures in the world today may be far more devastating than those in Dewey's own time.

Most importantly, when Dewey was writing a century ago, he was concerned with the problem of moral rigidity. However, educators in the 21st century are more likely to be confronted with the opposite problem of moral relativism. While the problem of moral rigidity may still be plaguing us, today's educators have a new challenge to combat-extreme moral relativism and decaying moral standards. It is time to renew Dewey's lessons for today. In this paper, I attempt to point out a new direction: that is, to acknowledge the importance of committed moral values in educational theory and practice. Although the questions of what values to choose, whose values count, and how to do this non-dogmatically, remain forever daunting, the creative task lies before us: to confront our own problems for our own times-but in a Deweyan, pragmatic spirit.

\section{Notes}

1. All references to Dewey's works are to The Collected Works of John Dewey, 1882-1953: The Electronic Edition, edited by Larry A. Hickman (Charlottesville, VA: InteLex, 1996). EW, MW, and LW are abbreviations for The Early Works, 1881-1898 (5 volumes), The Middle Works, 1899-1924 (15 volumes), and The Later Works, 1925-1953 (17 volumes).

\section{Works Cited}

Bourne, Randolph. "Twilight of Idols.” War and the Intellectuals: Essays by Randolph S. Bourne. Ed. Carl Resek. New York: Harpertorch Books, 1964. 53-64.

Dewey, John. German Philosophy and Politics. Ed. Larry Hickman. The Middle Works of John Dewey, Vol. 8. The Collected Works of John Dewey, 1882-1953: The Electronic Edition. Charlottesville: InteLex, 1996.

---. “Three Independent Factors in Morals.” Ed. Larry Hickman. The Later Works of John Dewey, Vol. 5. The Collected Works of John Dewey, 1882-1953: The Electronic Edition. Charlottesville: InteLex, 1996. 279-88.

---. Ethics. Ed. Larry Hickman. The Later Works of John Dewey, Vol. 7. The Collected Works of John Dewey, 1882-1953: The Electronic Edition. Charlottesville: InteLex, 1996.

---. Human Nature and Conduct: An Introduction to Social Psychology. Ed. Larry Hickman. The Middle Works of John Dewey, Vol. 14. The Collected Works of John Dewey, 1882-1953: The Electronic Edition. Charlottesville: InteLex, 1996.

---. "Outline of a Critical Theory of Ethics.” Ed. Larry Hickman. The Early Works of John Dewey, Vol. 3. The Collected Works of John Dewey, 1882-1953: The Electronic Edition. Charlottesville: InteLex, 1996. 239-388.

---. Art as Experience. Ed. Larry Hickman. The Later Works of John Dewey, Vol. 10. The Collected Works of John Dewey, 1882-1953: The Electronic Edition. Charlottesville: InteLex, 1996.

---. Experience and Nature. Ed. Larry Hickman. The Later Works of John Dewey, Vol. 1. The Collected Works of John Dewey, 1882-1953: The Electronic Edition. Charlottesville: InteLex, 1996.

---. “The Philosophy of the Arts.” Ed. Larry Hickman. The Later Works of John Dewey, Vol. 13. The Collected Works of John Dewey, 1882-1953: The Electronic Edition. Charlottesville: InteLex, 1996. 357-68.

---. Individualism, Old and New. Ed. Larry Hickman. The Later Works of John Dewey, Vol. 5. The Collected Works of John Dewey, 1882-1953: The Electronic Edition. Charlottesville: InteLex, 1996. 41-124.

---. Psychology. Ed. Larry Hickman. The Early Works of John Dewey, Vol. 2. The Collected Works of John Dewey, 1882-1953: The Electronic Edition. Charlottesville: InteLex, 1996.

Festenstein, Matthew. Pragmatism and Political Theory: From Dewey to Rorty. Chicago: University of Chicago Press, 1997.

Feuer, Lewis S. "Introduction to the Later Works of John Dewey.” Ed. Larry Hickman. The Later Works of John Dewey, Vol. 15. The Collected Works of John Dewey, 1882-1953: The Electronic Edition. Charlottesville: InteLex, 1996. xi-xxxiv. 
McVea, John F. “Constructing Good Decisions in Ethically Charged Situations: The Role of Dramatic Rehearsal.” Journal of Business Ethics 70 (2007): 375-90.

Nakamura, Kazuyo. “The Significance of Dewey’s Aesthetics in Art education in the Age of Globalization.” Educational Theory 29 (2010): 427-39.

Noddings, Nel. Philosophy of Education. Boulder: Westview Press, 1998.

Pappas, Gregory F. John Dewey's Ethics: Democracy as Experience. Bloomington: Indiana University Press, 2008.

Rogers, Melvin. The Undiscovered Dewey: Religion, Morality, and the Ethos of Democracy. New York: Columbia University Press, 2009.

Wang, Jessica Ching-Sze. John Dewey in China: To Teach and to Learn. Albany: State University of New York Press, 2007.

Uffelman, Mark. "Forging the Self in the Stream of Consciousness: Classical Currents of Self-cultivation in James and Dewey." Transactions of the Charles S. Pierce Society: A Quarterly Journal in American Philosophy 47 (2011): 319-39. 